\title{
PENGALAMAN KEPALA RUANG DALAM MENGELOLA ADMINISTRASI RUANGAN DI RUMAH SAKIT “AMELIA" PARE, KEDIRI
}

\section{EXPERIENCE HEADNURSE IN MANAGING WARD ADMINISTRATION AT HOSPITAL “AMELIA” PARE, KEDIRI}

\author{
Bambang Wiseno ${ }^{1 *}$ \\ ${ }^{1}$ Dosen Prodi Administrasi Kesehatan, Stikes Pamenang, Ex-Staff Nurse in MOH Kuwait. \\ * Korespondensi Penulis : bambangwiseno0601@gmail.com, bambangwiseno72@yahoo.com
}

\begin{abstract}
Abstrak
Peran perawat di rumah sakit yaitu memberikan asuhan keperawatan, advocator, educator, colaborator, coordinator, conselor dan researcher. Kepala ruang sebagai pimpinan dalam ruang perawatan mempunyai kewajiban dalam semua peran tersebut. Pengelolaan suatu ruangan di rumah sakit tidak terlepas dari kegiatan administrasi yang teratur dan terarah oleh semua tim yang ada di ruangan dalam mencapai tujuan. Peran perawat yang komplek tersebut akan bertambah beban kerjanya jika kurang didukung dengan tenaga profesional lain untuk menyelesaikan permasalahan yang ada di ruangan termasuk tenaga administrasi. Pelaksanaan administrasi tidaklah mudah kecuali oleh tenaga profesional yang telah mendapatkan pendidikan khusus keadministrasian. Masing-masing kepala ruangan mempunyai pengalaman pribadi ketika dituntut untuk menyelesaikan administrasi yang ada di ruangan tersebut. Penelitian ini bertujuan untuk menemukan makna dari pengalaman kepala ruang ketika mereka yang harus menyelesaikan semua permasalahan ruangan khususnya administrasi ruangan. Ini merupakan penelitian kualitatif dengan pengumpulan data melalui wawancara (indept intervew) terhadap semua kepala ruang (purposive sampling) sebagai partisipan dari rumah sakit "Amellia" Pare Kediri sesuai kriteria penelitian ini. Setelah data saturasi, dilakukan analisa data menggunakan IPA (Interpretative Phenomonology Analisys). Didapatkan sebanyak 6 (enam) tema, yaitu; merasa senang bisa membantu orang lain, bertanggungjawab atas keberhasilan akreditasi rumah sakit, bertanggungjawab atas masalah keperawatan di ruangan, merasa masalah ruangan tanggungjawab bersama staff, merasa beban berlebih karena administrasi selain urusan keperawatan dan merasa perlu ada petugas administrasi. Ruangan keperawatan perlu tenaga administrasi khusus untuk menyelesaikan keadministrasian yang ada di ruangan.
\end{abstract}

Kata Kunci: Beban Kerja, Perawat, Pelayanan, Administrasi, Kesehatan

\begin{abstract}
The role of nurses in hospitals is to provide nursing care, advocators, educators, collaborators, coordinators, counselors and researchers. The head nurses as a leader in the treatment room has obligations in all of these roles. Management of a ward in a hospital is inseparable from regular and directed administrative activities by all the teams in the ward in achieving their goals. The role of a complex nurse will increase the workload if it is not supported by other professionals to solve problems in the room including administrative staff. Implementation of administration is not easy except by professionals who have received special administrative education. Each Head Nurse has personal experience when required to complete the administration in the ward. This study aims to find the meaning of the experience of the head of the room when they have to solve all the problems of the room, especially room administration. This is a qualitative research by collecting data through interviews (indept interview) of all room heads (purposive sampling) as participants from the "Amellia" Pare Kediri hospital according to the criteria of this study. After saturation data, the data analysis done using IPA (Interpretative Phenomonology Analysis). Obtained as many as 6 (six) themes, namely; feel happy to be able to help others, is responsible for the success of hospital accreditation, is responsible for nursing problems in the ward, feels the problem of ward responsibilities with the staff, feels excessive burden due to administration other than nursing
\end{abstract}

Submitted $\quad: 17$ April 2020, Accepted : 8 Juni 2020

Website : jurnal.stikespamenang.ac.di | Email : jurnal.pamenang@gmail.com 
matters and feels the need for administrative officers. The ward needs special administrative staff to completely room administration.

Keywords: Workload, Nurse, Service, Administration, Health

\section{Pendahuluan}

Berdasarkan Peraturan Pemerintah Republik Indonesia Nomer 32 Tahun 1996 tentang tenaga kesehatan pada Bab II Jenis Tenaga Kesehatan pasal 2, ayat (5) disebutkan bahwa tenaga kesehatan masyarakat salah satunya adalah administrator kesehatan. Pada lampiran di Peraturan Menteri Kesehatan Nomor: 147/MENKES/PER/I/2010 Tanggal: 27 Januari 2010 disebutkan pula bahwa salah satu syarat dalam Izin Operasional Rumah Sakit dalam pada Sarana Prasarana salah satunya yaitu tersedianya ruang administrasi. Dimana dalam bidang administrasi harus tersedia administrasi manajemen yang terdiri dari administrasi umum dan administrasi keuangan.

Studi pendahuluan dengan wawancara terhadap beberapa kepala ruang di sebuah rumah sakit di Kediri tentang administrasi ruangan, mereka menyatakan bahwa merasa ada tambahan tanggung jawab karena harus mengurus semua administrasi yang ada di ruangan. Administrasi yang ada di ruang perawatan yang menjadi tanggung jawab kepala ruang yang harus diselesaikan, salah satunya tentang administrasi keuangan serta pengadaan barang di ruangan, disamping peran dan tanggungjawabnya sebagai pemberi asuhan keperawatan di ruangan. Selain itu mereka tidak pernah mendapatkan pendidikan tentang ilmu administrasi secara khusus dalam administrasi kesehatan.Administrasi Kesehatan haruslah dipegang oleh seorang yang tidak hanya mampu memahami dan menguasai tujuan dan fungsi dari perangkat administrasi, namun dapat memahami masalah di pelayanan kesehatan serta perlu memperhatikan bagaimana melaksanakan paradigma sehat dalam era desentralisasi.

Berdasarkan uraian diatas, kepala ruang di ruang perawatan selain sebagai pucuk pimpinan didalam mengelola pelayanan kesehatan berupa asuhan keperawatan di ruang perawatan juga mempunyai tugas sebagai pelaksana administrasi ruangan. Peran perawat sebagai tenaga kesehatan pada bagian keperawatan di pelayanan kesehatan juga bekerja pada bagian administrasi yagn diharuskan menguasai administrasi umum dan menguasai administrasi kesehatan.Untuk hal tersebut, peneliti ingin mengetahui lebih detail tentang pengalaman subyektif perawat sebagai kepala ruang yang mengelola semua administrasi di ruangan.

\section{Metode}

Penelitian kualitatif ini mengeksplorasi, menemukan, menguraikan dan menjelaskan kualitas pengalaman kepala ruang selama mengelola administrasi ruangan. Partisipan yang terlibat dalam penelitian ini sejumlah 9 (sembilan) orang kepala ruang yang sesuai dengan kriteria inklusi yang ditentukan melalui purposive sampling yaitu: 1) Perawat yang menjadi kepala ruang perawatan, 2) Partisipan yang bersedia terlibat dalam penelitian, 3) Partisipan bersedia diwawancarai dan direkam selama penelitian dan memberikan persetujuan publikasi hasil penelitian.

Proses rekruitmen partisipan pada penelitian ini dilaksanakan melalui permohonan dan ijin penelitian yang di sampaikan ke direktur rumah sakit "Amelia" Pare Kediri, yang kemudian tersampaikan kepada kepala ruang untuk membantu proses penelitian. Data dikumpulkan setelah partisipan menyetujui mengikuti penelitian dengan wawancara (indept intervew) serta mendengarkan curahan hati para kepala ruang. Wawancara yang dilakukan menggunakan panduan pertanyaan semi-terstruktur. Panduan berisikan tentang pengalaman kepala ruang dalam administrasi ruangan, persepsi akan beban kerja dalam kegiatan administrasi yang dirasakan oleh kepala ruang, harapan dan keinginan kepala ruang dalam kegiatan administrasi ruangan serta hambatan dan kesulitan yang dirasakannya. Selama wawancara peneliti juga menggunakan catatan lapangan(field note). Setelah data tercukupi selanjutnya peneliti melakukan analisa data menggunakan panduan menurut Linda, (2011), yaitu Interpretive Phenomenological Analysis (IPA) dengan alur sebagai berikut; read - re read, exploring semantic content, developing emergent themes, search connection across themes, bracket previous themes dan keep open minded to next case, 
looking for pattern across case dan taking interpretations.

Hasil

Partisipan sebanyak 9 (sembilan) orang kepala ruang dari rumah sakit"Amelia” yang berpendidikan sebagian besar adalah sarjana keperawatan, mempunyai pengalaman sebagai kepala ruang perawatan lebih dari 10 tahun. Partisipan telah mengikuti berbagai pelatihan untuk persiapan akreditasi rumah sakit. Menyatakan mengelola administrasi ruangan sejak pertama kali ditunjuk sebagai kepala ruang dengan dibantu anak buah (perawat dan pembantu perawat) sampai saat dilakukan penelitian.

Merujuk pada tujuan penelitian, ditemukan hasil sebanyak 6 (enam) tema, yaitu: 1) merasa senang bisa membantu orang lain, 2) bertanggung jawab atas keberhasilan akreditasi rumah sakit, 3) bertanggung jawab atas masalah keperawatan di ruangan, 4) merasa masalah ruangan tanggung jawab bersama staff 5) merasa beban berlebih karena administrasi selain urusan keperawatan dan 6) merasa perlu ada petugas administrasi. Berikut dijelaskan urutan penganalisaan data dari setiap tema yang ditemukan beserta penjelasan dari uraian masing-masing tema dan kategori dengan beberapa kutipan wawancara dari beberapa partisipan.

\section{1) Merasa senang bisa membantu orang lain}

Tema ini ditemukan dari ungkapan partisipan bahwa mereka "puas bisa membantu orang lain", maksud dari tema ini adalah ada rasa kepuasan dari kepala ruang bisa menyelesaikan pekerjaan yang ada walaupun itu bukan uraian tugasnya khususnya dalam hal administrasi, hal ini tampak ketika kepala ruang menyatakan seperti berikut:

“... ... puas sebenarnya, ketika (sedang) menyendiri (P7).

Puas dengan apa yang dikerjakan, ... ...dengan beban seperti itu (P8)

... ...iso nulungi kancane nulungi wong liyo (bisa menolong teman menolong orang lain), .... ... P4

\section{2) Bertanggung jawab atas keberhasilan akreditasi rumah sakit}

Akredirasi rumah sakit menuntut adanya kelengkapan semua data yang ada di rumah sakit sebagai tempat layanan kesehatan.
Kepala ruang merasa "kelengkapan akreditasi memerlukan perhatian", berikut partisipan mengungkapkan:

“... ... Apalagi sekarang untuk akreditasi berkas rekam medis kita berlomba-lomba untuk menyelesaikan (P5, P2).

“... .... apalagi dengan persiapan akreditasi sekarang ini ... ... (mengisyaratkan dengan tangan mengepal (filenote) dapat diartikan bahwa kepala ruang harus kuat) (P7)

“... ... Apalagi kalau persiapan akreditasi waahh $\quad . . \quad \ldots \quad y a a$ kita-kita (yang menyelesaikan) ...... (P3, P1)

Sebagai perawat sesuai dengan uraian tugasnya untuk persiapan akreditasi dengan; "bertanggung jawab menyelesaikan administrasi keperawatan". Maksud dari subtema ini adalah kepala ruang merasa bertanggung jawab atas kelengkapan data keperawatan yang berupa dokumentasi keperawatan, seperti yang disampaikan berikut ini:

“... ... dokumentasi keperawatan sangat memakan (perlu) waktu sekali, sehingga sebenarnya untuk urusan administrasi secara umum gak nyandak ... seperti billing, indikator mutu dan lain lain ( P2)

... ... maksudnya bebannya untuk administrasinya berapa jam untuk menyiapkan pasien operasi itu? ... .. (P3)

... ... pernah saya meniti (menghitung dengan hitungan menit) saya coba yaitu satu pasien datang anamnese menyiapkan satu itu kirakira sampai 40 menit, itu untuk satu pasien. kalau pasien lebih yaa lebih banyak waktu dan itu harus dikerjakan...... (P1).

\section{3) Bertanggung jawab asuhan keperawatan di ruangan \\ Di tema ini partisipan mengungkapkan} bahwa memberi pelayanan keperawatan "merupakan tanggung jawab perawat bila pekerjaan sesuai peran". Maksud dari tema ini adalah partisipan sebagai perawat harus bertanggung jawab terhadap semua yang berhubungan dengan keperawatan. Kutipan dari perasaan partisipan sebagai berikut:

... ... administrasi ruangan seperti menyiapkan obat, melengkapi berkas / status / melengkapi rekam medis, nah itu dibebankan kita gak apa"... ... (P2)

... ... padahal urusan pasien juga banyak yang harus diselesaikan. (P1) 
untuk perawat sendiri ada dokumentasi yang harus diselesaikan terkait dengan asuhan keperawatan yang dilakukan pada pasien, dan ini memang gak apa kalau kita yang menyelesaikannya (P10)

\section{4) Merasa masalah ruangan tanggung jawab bersama staff}

Di tema ini, partisipan mengungkapkan bahwa dalam tim keperawatan yang ada di ruangan saling membantu dan bekerja sama dalam menyelesesaikan semua permasalahan yang ada. "Menjadi tanggung jawab bersama semua staff" yang ada di ruangan semua masalah yang ada. Kutipan dari tema tersebut sebagai berikut:

... ... ruang harus berusaha untuk menyelesaikan administrasi ruangan walaupun itu bukan tugasnya dan menjadi beban tambahan... ... (P8)

... ... Ruangan yang tenaga terbatas mau tidak mau yaa kepontal-kepontal (kalang kabut) semua perawat mempunyai tanggung jawab yang sama dalam memberesi urusan administrasi ... ... (P6)

... ... Belum lagi kalau ada komplain pasien, dalam satu hari ada komplain pasien satu saja .. itu sudah menyita waktu satu hari sendiri karena harus segera diselesaikan dengan komite, direktur, wis pokoknya pontang panting ... (P5), ... ... itu kalau satu... lha kalau ada banyak?..... (P3)

... ... wong (dengan) satu complain saja bias memakan waktu satu dinasan. (P8)

\section{5) Merasa beban berlebih karena} administrasi selain urusan keperawatan.

Maksud dari tema ini adalah partisipan "merasa bahwa peran perawat banyak" sehingga partisipan merasa kesulitan untuk menyelesaikan administrasi yang ada apalagi yang bukan merupakan tanggung jawabnya. Kutipan subtema dari wawancara sebagai berikut:

... ... Akan menjadi beban ketika saat pasien banyak dan administrasi belum terselesaikan akhirnya punya beban ....... (P2)

... ... ganjalan. Ngene durung mari ngono durung (ini belum itu belum) selesai padahal harus ngopeni (merawat) pasien, munculnya saat itu ... ... (P7)

... ... saya mengambil karena saya mau operasi sehingga harus cepat dan lengkap persyaratannya operasi. (P4)
Kepala ruang yang membawahi semua staff di ruangan juga "merasa terbebani dengan administrasi profesi lain" yang dialami oleh semua staff perawat yang ada. Kutipan apa yang dirasakan oleh kepala ruang sebagai berikut:

... ...lhaaa maksudnya itu.. kalau tidak diambil tidak di antarkan. makanya biar tidak gegeran (bertengkar/salah paham) $(P 1)$

... ... balik itu lagi, itu sebenarnya bagian tugas radiologi, sering kita mengambilnya sehingga menjadi tambahan beban ruangan. (P9)

..... Cuma ini sebenarnya kalau (instalasi) gizi (berkas) dilengkapi dengan benar maka tidak membebani lainnya (perawat)...... (P2)

...itu menjadi salah satu beban administrasi ruangan untuk menyampaikan ke (instalasi) $\operatorname{gizi}(P 4)$

Satu hal lagi yang menurut kepala ruang menjadi beban yaitu ketika menyelesaikan urusan pembiayaan. Kepala ruang merasa "keberatan dengan administrasi keuangan", karena mereka tidak mempunyai pendidikan khusus keadministrasian dalam keuangan, sehingga jika terjadi kesalahan dalam menyelesaikan administrasi keuangan akan menambah beban bagi kepala ruang sebagai pengelola ruang perawatan. Ungkapan tersebut seperti pada kutipan dibawah ini:

... ... Sebenarnya billing bukan tanggung jawab kita tapi kita semua harus bisa karena tidak ada yang menyelesaikan kalau bukan perawatan. $(P 10)$

... ... ... Billing juga sangat membebani karena harus satu persatu keuangan dari semua kegiatan perawat dimasukkan ke komputer, dan waaah itu kalau salah masuk, juga perawat yang disalahkan padahal urusan pasien juga banyak yang harus diselesaikan. $(P 1, P 2)$

\section{6) Merasa perlu ada petugas administrasi}

Di tema ini merupakan harapan dari kepala ruang tentang "tenaga khusus administrasi ruangan". Partisipan berharap ada tambahan tenaga yang menyelesaikan keadministrasian khususnya yang berhubungan dengan masalah keuangan atau pembiayaan selama pasien mendapat perawatan di ruangan. Ungkapan partisipan mengenahi tema ini sebagai berikut: 
... ... sehingga beban administrasi menjadi berkurang dengan adanya petugas administrasi ruangan ... ... (P3)

... ... sepertinya perlu administrasi khusus untuk ruangan menyelesaikan seтиа urusan di ruangan termasuk billing, data-data sismodar dan mungkin itu perlu untuk meringan kan beban ruangan ... ... (P3, P5) ... ... kalau ada administrasi yang keliling ke ruangan untuk menyelesaikan urusan duit atau solusinya dengan menempatkan satu petugas admin untuk menyelesaikan keuangan pasien di ruangan seperti di RS Iskak (salah

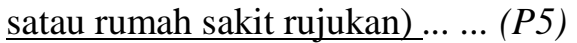

\section{Pembahasan}

\section{1) Merasa senang bisa membantu orang} lain

Bekerja dalam tim memerlukan kesadaran untuk saling membantu dan bekerja sama (Riana, 2019). Kelapa ruang mendapatkan kepuasan tersendiri ketika bisa membantu menyelesaikan permasalahan yang ada di rumah sakit selain kesibukannya dalam memberikan asuhan keperawatan dan peran lainnya. Kepala ruang dalam tatalaksana layanan di ruangan mempunyai pengalaman yang berbeda-beda, dipenelitian ini didapatkan bahwa mereka merasa puas ketika masih dapat membantu orang lain dalam hal ini pekerjaan yang seharusnya dikerjakan oleh unit lain. Kepala ruang adalah seorang perawat yang berpendidikan lebih dari perawat lainnya dan mempunyai pengalaman lebih dimana tingkat pendidikan ini mempengaruhi kepuasan kerjanya (Nuriza, 20108). Seseorang akan merasa senang bila hasil kerjanya bermanfaat untuk orang lain begitu juga kepala ruang yang disela-sela kesibukannya masih dapat menyelesaikan tugas sesuai selain tanggung jawabnya. Walaupun ada pendapat yang menyatakan bahwa pemberdayaan structural merupakan model yang dapat digunakan meningkatkan kepuasan kerja perawat (Arini, 2018).

\section{2) Bertanggung jawab atas keberhasilan akreditasi rumah sakit}

Kepala ruang dengan pengalaman beberapa tahun di rumah sakit menunjukkan rasa tanggung jawab dan kepedulian dengan institusi yang ikutinya. Rumah sakit sebagai tempat layanan masyarakat mempunyai tanggung jawab memberikan pelayanan yang baik dan berstandart sesuai dengan undang- undang yang ada. Seluruh staff karyawan berkewajiban untuk mendapatkan hasil akreditasi yang optimal. Kepala ruang sebagai pimpinan perawat di ruangan perawatan dalam partisipasinya untuk mensukseskan hasil akreditasi rumah sakit akan selalu berusaha melakukan kegiatan dengan penerapan standar sesuai dengan bidang dan tanggung jawabnya (Hendroyogi \& Harsono, 2016).

Pendidikan terendah dari kepala ruang yang ada di rumah sakit Amelia adalah Sarjana Keperawatan, dengan tingkat pendidikan ini kepala ruang pastinya mempunyai tanggung jawab yang besar. Tanggung jawab pekerjaan ini dapat berpotensi mempengaruhi persepsi dan partisipasi terhadap akreditasi rumah sakit. (Simanjuntak \& Napitupulu, 2019). Sehingga apa yang menjadi tanggung jawab kepala ruang sangat penting dalam pelaksanaan akreditasi rumah sakit, terlebih dalam kelengkapan data pelayanan keperawatan. Keterlibatan kepala ruang dalam berpartisipasi untuk akreditasi rumah sakit secara psikologis akan meningkatakan rasa tanggung jawabnya (Simanjuntak \& Napitupulu, 2019), untuk mendapatkan hasil maksimal. Kepala ruang sebagai pengelola perawat di ruangan mempunyai tanggung jawab atas kelengkapan dokumentasi untuk persiapan ketika dibutuhkan dalam akreditasi.

\section{3) Bertanggung jawab asuhan keperawatan di ruangan}

Sebagai pimpinan di ruang perawatan, kepala ruang sesuai uraian kerjanya bertanggung jawab terhadap semua kegiatan di ruangan. Kewajiban ini tentunya ditekankan pada pekerjaan yang sesuai tanggung jawab yang diberikan kepadanya (Yahya, 2019). Semua kegiatan keperawatan di ruangan berada dalam tanggung jawab kepala ruang, sehingga sesuai dengan salah satu perannya di layanan kesehatan yaitu sebagai pemberi asuhan keperawatan. Kegiatan yang berhubungan dengan asuhan keperawatan di ruangan semua berada dalam kendali kepala ruang. Jika terjadi suatu permasalahan dalam asuhan keperawatan maka kepala ruang bertanggung jawab untuk membagi tugas dan diselesaikan bersama (Riana, 2019). 


\section{4) Merasa masalah ruangan tanggung jawab bersama staff}

Dalam organisasi semua bagian mempunyai tanggung jawab untuk organisasi tersebut bisa berjalan sesuai yang diharapkan. Ruang perawatan sebagai organisasi yang diketuai oleh kepala ruang terjadi berbagai macam kegiatan kesehatan selain keperawatan tentunya tidak terlepas dari masalah. Semua staff di ruangan bertanggung jawab sesuai uraian kerja masing-masing namun untuk menghindari ketidaklancaran dalam operasional ruangan kadang staff yang ada harus melakukan pekerjaan selain uraian tugasnya (Hendroyogi \& Harsono,2016).

Menurut Novelia, Swasto \& Ruhana, (2016) dalam penelitiannya menyebutkan bahwa organisasi membutuhkan pekerja yang mendahulukan kepentingan bersama daripada kepentingan pribadi demi kelangsungan organisasinya dan bertanggung jawab dengan terlibat didalamnya. Sebagai suatu organisasi yang berupa ruang perawatan, kepala ruang dan semua staff berkewajiban dan bertanggung jawab terhadap permasalahan yang ada sesuai dengan uraian tugasnya, namun kemungkinan mengerjakan bagian lain untuk menghindari ketidaklancaran kegiatan organisasi tersebut.

\section{7) Merasa beban berlebih karena administrasi selain urusan keperawatan}

Pekerjaan layanan kesehatan di ruangan tidak hanya khusus keperawatan namun kegiatan dari berbagai unit / instalasi di rumah sakit. Kadang banyak pekerjaan yang bukanmenjadi uraian tugas kepala ruang harus dikejakan oleh kepala ruang. Ketika hal itu lebih banyak dari tenaga perawat yang tersedia maka ruang perawatan tersebut memiliki beban kerja yang berat (Maharja, 2015).

Maharja (2015), juga menyampaikan bahwa aktifitas kerja kepala ruang sangat banyak tanggung jawabnya, baik tanggung jawab secara lisan dan tulisan termasuk dalam hal ketatalaksanaan ruangan secara administrasi. Tanggung jawab tersebut di rasakan menjadi beban ketika tidak mampu menyelesaikan apalagi yang tidak sesuai dengan uraian tugas kepala ruang sebagai pimpinan perawat di ruangan. Kadang perawat harus menyelesaikan kerjaan yang menjadi tanggung jawab profesi lain, hal ini dilakukan untuk menghindari ketidaklancaran kegiatan di ruangan. Beban ini kadang dengan terpaksa dilakukan untuk menghindari masalah lain yang mungkin muncul ketika akreditasi.

Tidak jauh berbeda dengan apa yang disampaikan oleh Sari, Harijanto, \& Susilo, (2018) bahwa keterlambatan dalam penyelesaian administrasi dapat mempengaruhhi kegiatan lain di ruang perawatan, sehingga kepala ruang sebagai pengelola ruang perawatan bersama tim ruangan membantu menyelesaikan urusan administrasiuntuk mengurangi masalah di ruangan walaupun ini membebani mereka.

Untuk menghindari tumpang tindih pekerjaan dan mengurangi beban,sebenarnya sudah ada pedoman tentang hal itu yaitu dengan membagi beban kerja di setiap unit kerja berdasarkan target pekerjaan untuk setiap jabatan (Menpan, 2004). Kurangnya sosialisasi uraian tugas pada pekerja dapat menyebabkan tumpang tindih kerjaan sehingga beban kerja tidak seimbang.

\section{8) Merasa perlu ada petugas administrasi.}

Pada penelitian yang dilakukan oleh Africia (2017), menyebutkan bahwa kegiatan administrasi tidak berhubungan dengan kinerja perawat. Kegiatan administrasi bukanlah kegiatan utama dari perawat, namun dikenyataannya administrasi masih dilakukan oleh sebagian perawat. Disebutkan juga dipenelitiannya bahwa tenaga administrasi tidak mampu mengatasi sehingga perawat yang berada diruangan secara aktif membantu menyelesaikannya. Sehingga jika melihat dari keadaan tersebut sekiranya perlu rumah sakit untuk menyediakan tenaga administrasi diruangan yang khusus menyelesaikan urusan keadministrasian.

Penambahan tenaga administrasi kesehatan di ruangan sepertinya perlu untuk adakan sehingga beban perawat bisa lebih terfokus sesuai perannya yaitu sebagai pemberi asuhan keperawatan, colaborator, educator, advocator, coordinator, conselor dan sebagai researcher dapat dikerjakan.

\section{Kesimpulan}

Berdasarkan hasil penelitian dapat disimpulkan bahwa kepala ruang dalam mengelola administrasi diruangan merasa bertanggung jawab atas semua masalah yang ada di ruangan tersebut walaupun kadang apa yang dikerjakan bukan merupakan uraian tugasnya. Sehingga kepala ruang merasa perlu 
ada sosialisasi kejelasan uraian tugas dari semua unit di rumah sakit sehingga tidak ada tumpang tindih pekerjaan yang dapat menambah beban bagi perawat. Disamping itu kepala ruang merasa perlu adanya tambahan tenaga administrasi untuk menyelesaikan administrasi, khususnya dalam administrasi keuangan di ruangan. Kepala ruang menyampaikan bahwa beban kerja yang bertambah karena unit lain akan dirasakan berat ketika perannya sebagai perawat belum terselesaikan. Namun kepala ruang akan merasa puas dan senang ketika bisa membantu unit lain disaat senggang dan uraian tugas perawat telah terselesaikan semua.

\section{Saran}

Kepala ruang sebagai pengelola ruangan pelayanan disarankan perlu untuk mengerti tentang administrasi umum selain administrasi keperawatan sehingga mampu untuk mengendalikan seluruh proses layanan. Dalam optimalisasi mutu di layanan kesehatan, semua unit di layanan kesehatan akan berjalan dengan baik bila sistem administrasi di masing-masing unit terselesaikan dengan baik. Koordinasi dari semua unit akan terjalin dengan baik jika paham dalam menjalankan uraian tugas masing-masing sehingga kesiapan dalam akreditasi rumah sakit lebih baik dengan kelengkapan administrasinya. Tumpang tindih pekerjaan yang dialami oleh kepala ruang menjadi beban tambahan sehingga perlu adanya tenaga khusus yang menangani administrasi ruangan, sehingga kepala ruang dapat terfokus memberikan yang terbaik untuk pasien dan ketersediaan berkas keperawatan untuk akreditasi rumah sakit.

\section{Ucapan terima kasih}

Penulis sampaikan terima kasih kepada direktur dan seluruh staff rumah sakit Amelia Pare Kediri yang berada di Jln. Pahlawan 25 A Pare Kediri, khususya kepala ruang serta kepada Lembaga Penelitian dan Pengabdian Masyarakat (LPPM) Stikes Pamenang Kediri yang telah membantu penelitian ini.

\section{Daftar Pustaka}

Anonimous, 2010. Peraturan MenteriKesehatan Nomor: 147/MENKES/PER/I/2010 Tanggal: 27 Januari 2010 tentang Ijin Operasional Rumah Sakit

Smith, J.A., Flower, P. \& Larkin, M. 2009. Interpretative Phenomenological Analysis:
Theory, Method and Research. London: Sage.

Linda, S. 2011. Phenomenology for Therapists. Researching the lived World. Publiser WileyBlackwell. $\quad$ 1st Edition, ISBN-13: 9780470666456

Riana, L. W. 2019. Pengaruh Kerjasama Tim Dan Kepuasan Kerja Terhadap Kualitas Pelayanan. PSIKOBORNEO, 2019, 7 (1) : 232-242 ISSN 2477-2674 (online), ISSN 2!477-2666(cetak), ejournal.psikologi.fisipunmul.ac.id

Nuriza, A. 2018. Hubungan Karakteristik Dan Sikap Perawat Dengan Kepuasan Kerja Dalam Pelaksanaan Peran Kolaborasi Perawat Dan Dokter di Ruang Rawat Inap Rumah Sakit Umum Bunda Palembang Tahun 2018 (Doctoral dissertation, UNIVERSITAS ANDALAS).

Arini, T. 2018. Budaya Keselamatan Pasien Berbasis Pemberdayaan Struktural Dengan Kepuasan Kerja Perawat (Doctoral dissertation, Universitas Airlangga).

Hendroyogi, S., \& Harsono, M. 2016. Keterkaitan antara Persepsi Pentingnya Akreditasi Rumah Sakit Dengan Partisipasi, Komitmen, Kepuasan Kerja, dan Kinerja Karyawan. Jurnal Manajemen Dayasaing, 18(2), 122-137.

Simanjuntak, E., \& Napitupulu, B. 2019. Analisis Ketidaklengkapan Dokumen Rekam Medis Menurut Standar Akreditasi Rumah Sakit Mki19.1 Versi Kars 2012 Di Rumah Sakit Umum Imelda Pekerja Indonesia (Rsu Ipi) Medan Tahun 2018. Jurnal Ilmiah Perekam dan Informasi Kesehatan Imelda, 4(1), 533 536.

Yahya, A. 2019. Pengalaman Penerapan Indikator Kinerja Individu Staf Klinis Dengan Menggunakan e-Log Book Di Rumah Sakit Pertamina Cirebon. The Journal of Hospital Accreditation, 1(1).

Novelia, M., Swasto, B., \& Ruhana, I. 2016. Pengaruh Komitmen Dan Organizational Citizenship Behavior (OCB) Terhadap Kinerja (Studi Pada Tenaga Keperawatan Rumah Sakit Umum Daerah Dr. Soegiri Lamongan). Jurnal bisnis, 38(2), 71-78.

administrasi

Maharja, R.2015. Analisis tingkat kelelahan kerja berdasarkan beban kerja fisik perawat di instalasi rawat inap RSU Haji Surabaya. The Indonesian Journal of Occupational Safety and Health, 4(1), 93-102.

Sari, D. P., Harijanto, T., \& Susilo, H. 2018. Analisis Akar Masalah Panjangnya Waktu Tunggu Proses Administratif Pemulangan Pasien Rawat Inap. Journal of Nursing Care 
Africia, F. 2017. Hubungan Beban Kerja Perawat Dengan Kinerja Perawat Di Bangsal Instalasi Rawat Inap RSUD Mardi Waluyo Kota Blitar. JuKe (Jurnal Kesehatan), 1(1). 